\title{
KONSEP KESELAMATAN DALAM AL-QUR'AN
}

\author{
Salamah Eka Susanti*
}

Abstract: The doctrine of salvation is an important concept that is common to every religion. Therefore, each religion claims to be the savior (Salvator) for each of its followers. In Protestant Christianity for example, there is a doctrine known as "No Salvation Outside Christianity", beyond Christianity there is no salvation. Likewise in Catholic Christianity, adhering to, a doctrine that mentions "Extra Ecclesiam Nulla Salus", outside the church there is no salvation. For Judaizers, the doctrine of "The Chosen People" becomes their theological foundation that only Jews will gain salvation. Whereas in Islam itself, the theological argument of salvation as their own is based on the doctrine of ultimate cessionism (ie, Christianity and Judaism) remains valid before the coming of the new (Islamic) rule that replaces the old rule, the new rule by itself cancel the previous rule. This argument is based primarily on the verse (إن الد ين عند الله الهاء سلام).If historically examined, all religions without exception, both tertiary and non-theistic are born and have a claim to the truth about the assurance of salvation, whether expressed explicitly or implicitly. In other words, no religion does not have a doctrine of salvation because the claim of salvation is something that is already inherent in every religion.

Keywords: Concepts, Salvation, Al-Qur'an.

\section{A. Pendahuluan}

Dalam setiap agama terdapat perbedaan yang cukup signifikan

* Penulis adalah Dosen Tetap Institut Ilmu Keislaman Zainul Hasan (INZAH) Kraksaan Probolinggo. 
dalam memandang klaim keselamatan, jika dipetakan secara garis besar setidaknya terdapat 3 klasifikasi pandangan yang muncul berkaitan dengan klaim keselamatan, yaitu eksklusivisme, inklusivisme dan pluralisme.

Jika di hubungkan ketiga paradigma tentang klaim keselamatan, khususnya keselamatan bagi non muslim, maka tafsir yang berorientasi tekstual pada prinsipnya bersifat eksklusif, yaitu memandang klaim kebenaran dan keselamatan secara ekslusif hanya dimiliki oleh kalangan orang-orang yang menganut Islam sebagai agama yang dibawa oleh Nabi Muhammad. Sedangkan tafsir yang berorientasi kontekstual menampilkan teks-teks al-Qur'an yang berkaitan dengan keselamatan kaum non muslim dalam perspektif ketuhanan Universal dan Inklusivistik, yaitu melihat kaum ahli kitab sebagai muslim karena mereka tetap menjalankan keimanan dan berbuat baik sehingga berhak untuk memperoleh keselamatan di akhirat.Keselamatan erat kaitannya dengan tingkat keimanan terhadap Tuhan dan perbuatan amal shaleh yang mereka kerjakan. Keselamatan dan kebahagiaan di akhirat tidak didasarkan atas status agama (formal) seseorang, apakah ia seorang muslim, Yahudi, Nasrani atau Sabi' in, tetapi lebih di dasarkan pada keimanan yang benar (Sabib) dan amal saleh yang di lakukannya.

Pemahaman yang lebih kontemporer tentang konsep keselamatan, definisi Islam adalah mengakui adanya Allah, beriman pada hari akhir dan beramal shaleh.Dengan demikian, siapa saja yang memiliki ketiga sifat itu disebut sebagai Muslim, tanpa melihat apakah dia termasuk pengikut Muhammad (alladzina 'Amanu), pengikut Musa (al-Yahud), Isa (An-Nasara) atau pengikut jalan keselamatan lainnya.

\section{B. Konsep Keselamatan dalam Al-Qur'an Perspektif Tafsir Tekstual}

Ada tiga kata kunci penting yang bermakna keselamatan dalam alQur'an, yakni $A n-N a j a h, A s-s a l a m$ dan Inqaz.Kendati masih ada terma yang semakna dengan ketiga kata kunci di atas.Sengaja penulis hanya memilih ketiga kata kunci ini, karena ketiganya berkaitan dengan keselamatan dalam bidang keyakinan.

Konsep keselamatan yang khusus menunjuk pada konsep keselamatan (Salvation) di akhirat adalah terma an-Najah. Ayat-ayat tentang an-Najah 
yang berarti keselamatan, diantaranya adalah Qs.Hud : 58, Qs. Fusilat: 18, Qs. Al-Mukmin : 41, Qs. Ad-Dukhan : 30, Qs. Az-Zumar: 61, QS. Yunus: 103, Qs. Maryam : 72 dan Qs. As-Saf: 10.Dalam konteks terma $A n$-Najah, secara umum penafsiran yang beroerintasi tekstual memahami ayat-ayat yang berkaitan denganmasalah ini sebagai penegasan terhadap jalan keselamatan yang akan diperoleh oleh orang-orang yang beriman kepada Allah dan berbuat kebajikan, misalnya seperti yang ditunjukkan oleh Qs. Hud: 58 dan Fussilat :18. Pada dua ayat ini, Qutb misalnya memahami bahwa konteks ayat itu ditujukan kepada kaum yang setia pada ajaran-ajaran monoteisme yang dibawa para Nabi. Dalam hal ini, Qutb mengakui bahwa keberimanan mereka masih tetap dalam koridor monoteisme meskipun mereka berasal dari kaum Nabi sebelum Nabi Muhammad, mereka tetap mendapatkan keselamatan di akhirat. ${ }^{1}$ Tafsir yang berorientasi tekstual memandang ayat-ayat diatas secara eksplisit mengandung arti bahwa keselamatan hanya peroleh oleh mereka yang beriman pada Allah, beramal shaleh dan memeluk agama Islam.

Sedangkan konsep keselamatan yang terkandung dalam kata asSalam, yang berarti perdamaian (Sulh) dan mencari selamat (Istislam) seperti yang terdapat dalam (Qs. An-Nahl : 87, Qs. Asy-Syu'ara: 8-89). Kata Salamun yang artinya selamat, aman, damai dan sejahtera, seperti yang terdapat dalam (Qs. Al-An'am : 127). Dalam ayat ini, konsep keselamatan di artikan sebagai selamat dari petaka, bahaya dan berbagai kesukaran seperti yang menimpa penduduk neraka ${ }^{2}$. Terkait yang term as-Salam, seperti dalam Qs. Asy-Syu'ara: 88-89, Qutb dan Maududi, menafsirkan sebagai konsep keselamatan yang terkait dengan "Keimanan dan ketulusan dalam menjalankan syari'at Tuhan" yaitu syari'at yang dibawa oleh Nabi Muhammad. ${ }^{3}$

Terma lain yang juga mengandung konsep keselamatan adalah alInqaz, seperti yang terdapat pada ayat, Qs. Yasin: 23 dan 43. Konsep keselamatan dalam terma al-Inqaz ini mengandung arti keselamatan yang berlaku di dunia dan akhirat.Terma Al-Inqaz pada kedua ayat itu dalam sejumlah tafsir tradisional dan modern memang diartikan dengan

1 Qutb, Fi Zilal Al-Qur'an, Jilid 1, hal. 424.

2 Imam al-Baidawi, tafsir al-Baidawi al-Musamma Anwar at-Tanzil wa Asrar at-Ta'wil, Jilid III (Beirut: dar al-Fikr, 1996) hal. 191.

3 Ibid., hal. 325 
"menyelamatkan" dan "diselamatkan" ${ }^{5}$ Namun demikian,konteks ayat ini sebenarnya ditujukan kepada orang-orang yang berserah diri hanya pada Tuhan, dengan demikian mereka akan diselamatkan dari siksa api neraka. Jika diteliti pada ayat selanjutnya, yaitu ayat ke 45, maka makna "diselamatkan" (ayat: 43) tidak hanya di berlakukan di dunia, tetapi juga di akhirat. ${ }^{6}$

Jika di hubungkan ketiga paradigma tentang klaim keselamatan, khususnya keselamatan bagi non muslim, maka tafsir yang berorientasi tekstual pada prinsipnya bersifat eksklusif, yaitu memandang klaim kebenaran dan keselamatan secara ekslusif hanya dimiliki oleh kalangan orang-orang yang menganut Islam sebagai agama yang di bawa oleh Nabi Muhammad.Mengenai Q.S.Al-Baqarah;62, Oleh tafsir tekstual, ayat ini dipahami sebagai suatu justifikasi akan keberadaan agama-agama lain di luar Islam, namun justifikasi itu hanya pada aspek eksistensinya, bukan pada aspek kebenaran yang dikandung oleh agama-agama tersebut. Tegasnya, ayat ini sama sekali tidak melegitimasi kebenaran agama di luar Islam atau menjadi justifikasi adanya jalan keselamatan bagi umat Yahudi, Nasrani, dan Sabi' in sebagaimana yang menjadi keyakinan tafsir yang berorientasi kontekstual.

Terhadap QS. Al-Baqarah : 62, Ibnu Katsir menegaskan keselamatan hanya diperoleh oleh mereka yang nyata-nyata memeluk agama Islam yang di bawa oleh Nabi Muhammad karena pada dasarnya tidak ada agama yang diterima dari sisi Allah selain Islam. ${ }^{7}$

Sejalan dengan Ibnu Katsir, Sayyid Qutb, menjelaskan bahwa keselamatan hanya di sediakan oleh Islam yang berupa penyerahan diri kepada Allah, ketaatan terhadap syari'atnya dan mengikuti Rasulnya. ${ }^{8}$

Dari beberapa penjelasan di atas, jelaslah bahwa mayoritas penafsiran yang berorientasi tekstual meyakini bahwa hanya ada satu agama ( $A l$ $D i n)$ yaitu Islam sebagai jalan keselamatan. Hanya dengan melalui jalan inilah seseorang akan memperoleh keselamatan.

${ }^{4}$ Qs. Yasin ayat : 23

${ }^{5}$ Qs. Yasin ayat : 43

${ }^{6}$ Ibnu Katsir, TafisrAl-Qur'an, Jilid II.Hal. 280-281

7 Ibnu Katsir, Tafsir Al-Qur'an Al-Adzim, Jilid I (Beirut: Dar Al-Kutub AlIlmiyah, 2000), hal, 347.

${ }^{8}$ Sayyid Qutb, Fi Zilal Al-Qur'an, Jilid I, cet. Ke-21 (Beirut: Dar al-Syuring, 1993), hal. 364. 


\section{Konsep Keselamatan dalam Al-Qur'an : Perspektif Tafsir Kontekstual}

Islam sebagai ajaran yang dibawa oleh para Nabi dan Rasul membawa misi keselamatan dan kesejahteraan baik di dunia dan akhirat. Hal ini sesuai dengan makna terma Islam sendiri yang berasal dari akar kata Salima dan derivasi kata bentukannya, Salamun, yang berarti keselamatan atau kesejahteraan.

Secara umum, tafsir yang berorientasi kontekstual menampilkan teksteks al-Qur'an yang berkaitan dengan keselamatan kaum non muslim dalam perspektif ketuhanan Universal dan Inklusivistik. Rasyid Ridha yang penafsirannya cenderung kontekstual misalnya, melihat kaum ahli kitab sebagai muslim karena mereka tetap menjalankan keimanan dan berbuat baik sehingga berhak untuk memperoleh keselamatan di akhirat. Syari'at yang diturunkan pada mereka adalah syari'at yang mengandung ajaran monoteisme dan ketulusan beribadah pada Tuhan. ${ }^{9}$ Sebagaimana Rasyid Ridha, Muhammad Abduh juga sependapat dengan Rasyid Ridha.

Premis yang digunakan mufasir kontekstual terhadap posisi ahli kitab ini adalah pernyataan al-Qur'an yang secara eksplisit mengakui keabsahan secara de jure semua agama wahyu dalam dua hal yaitu: Pertama, menerima keberadaan kehidupan religius komunitas lain yang semasa dengan kaum muslim awal, menghormati hukum-hukum, norma-norma sosial dan praktek keagamaan-keagamaan mereka.Kedua, menerima pandangan bahwa pemeluk-pemeluk setiap agama-agama ini juga akan mendapatkan keselamatan di akhirat (Qs. Al-Baqarah : 62). Kedua aspek sikap al-Qur'an terhadap kaum ahli kitab ini dapat dianggap sebagai dasar penerimaan pluralisme agama dan keyakinan. Penerimaan terhadap mereka tidak hanya dari sisi sosio-religius semata, tetapi juga dari sisi kehidupan spiritual mereka dan keselamatan melalui jalur yang berbeda.

Terkait dengan terma an-najah, tafsir kontekstual memahaminya dalam konteks keimanan moneteristik dan perbuatan amal shaleh tanpa memandang identitas keberagaman formal mereka.Hal ini sesuai dengan asumsi teologis penganut tafsir kontekstual (bahwa keselamatan di akhirat menghendaki tiga syarat utama yaitu, Iman, Islam dan amal

\footnotetext{
9 Rasyid Ridha, Tafsir Al-Qur'an al-Hakim, hal. 332.
} 
shaleh.Seperti Murtadha Muthahhari misalnya, menggaris bawahi bahwa syari'at keselamatan dalam Islam. Artinya keselamatan tidak dapat di monopoli kaum muslimin semata, tetapi juga menjadi hak kaum non muslim selama mereka percaya beriman kepada Tuhan, percaya pada kenabian Muhammad dan mengerjakan amal shaleh. ${ }^{10}$

Dengan penafsiran semacam itu, dapat digaris bawahi bahwa keselamatan erat kaitannya dengan tingkat keimanan terhadap Tuhan dan perbuatan amal shaleh yang mereka kerjakan.Keselamatan menjadi hak setiap orang yang beriman dan beramal saleh dari agama apapun mereka berasal. Dengan kata lain, setiap agama yang mengajarkan keimanan monoteistik terhadap Tuhan dan amal shaleh dapat menjadi jaminan bagi pemeluknya untuk memperoleh keselamatan dan rahmat di akhirat.

Dengan menganalisis terma an-Najah, dapat disimpulkan bahwa bicara keseluruhan terma ini memiliki makna positif, yaitu dalam pengertiansetiap orang yang beriman kepada Allah, beramal shaleh dan percaya hari akhir, maka ia akan di jamin memperoleh keselamatan di akhirat Rasyid Ridha, dan Muhammad Abduh menyebut setiap bentuk keimanan terhadap Tuhan dan perbuatan shaleh akan ada jaminan keselamatan di akhirat tanpa memandang identitas formal keagamaan yang dianut mereka. ${ }^{11}$

Selanjutnya dengan term Salam, Qs. Asy-Syu'ara : 88-89, terma "Salam" diartikan sebagai "yang suci". Dalam hal ini Murtadha Muthahhari misalnya, menjelaskan bahwa makna Fi Qalbin Salim adalah " hati yang suci". Dalam konteks keseluruhan ayat ini, "hati yang suci" sebagai cermin keimanan seseorang dijadikan sebagai syarat untuk memperoleh keselamatan di akhirat.Artinya keimanan sebagai syarat utama keselamatan di maknai sebagai keimanan yang mampu mendorong pemiliknya untuk melakukannya ketundukan hati sebagai penyerahan, total dirinya sebagai manusia pada Allah, tidak peduli agama formal apapun yang dianut dan diyakini. ${ }^{12}$

Beralih pada terma terakhir, yaitu terma Inqaz, seperti yang di jelaskan pada bagian tafsir tekstual diatas, al-Inqaz memang bermakna

${ }^{10}$ Murthadha Muthhari, Keadilan Illabi, (Asas Pandangan Dunia Islam), terj. Agus Efendi, Bandung: Mizan, 1977,hal, 234-235.

${ }^{11}$ Rasyid Ridha, Tafsir al-Qur'an al-Hakim, Jilid IV, hal. 258.

${ }^{12}$ Murtadha Muthahhari, Keadilan Illabi, hal. 241-242. 
“menyelematkan" (ayat: 23) dan "diselamatkan" (ayat : 43) seperti pandangan tafsir tekstual, tafsir kontekstual memandang makna "menyelamatkan" dan di "selamatkan" juga di berlakukan baik dunia maupun di akhirat namun pemberlakuan konsep-konsep "menyelamatan" dan "diselamatkan" itu tidak terbatas pada orang-orang secara formal memeluk agama Islam saja tetapi justru mencakup juga kepada orangorang yang pada prinsipnya beriman dan menyerahkan dirinya secara total kepada Allah, mempercayai hari akhir dan berbuat kebajikan. ${ }^{13}$ Rasyid Ridha mengatakan bahwa Allah tidak akan menyia-nyiakan keberimanan seseorang dan kebaikannya, apapun identitas keagamaan yang dianutnya. Hal ini diperkuat oleh pendapat Ibnu al-Arabi ketika menafsirkan ayatayat yang mengindikasikan adanya pluralisme agama.Dengan konsep wabdah al-Adyan Ibnu al-Arabi menyatakan bahwa pluralisme agama tetap terikat baik secara eksoterik-fenomenologis maupun secara esoteris pada aspek keimanan dan keyakinan yang ditujukan hanya kepada Tuhan yang disertai perbuatan baik.Artinya meskipun secara "Syari'at" setiap orang atau kelompok memiliki jalannya masing-masing, keimanan kepada Tuhan yang disertai perbuatan baik tetaplah bersifat lintas Agama (Cross - Religion). ${ }^{14}$

Muhammad Rasyid Ridha dalam tafsirnya, Al-Manar, ketika menafsirkan (Qs. Al-Baqarah: 62) menegaskan bahwa keselamatan dan kebahagiaan di akhirat tidak didasarkan atas status agama (formal) seseorang, apakah ia seorang muslim, yahudi, nasrani atau sabi'in, tetapi lebih didasarkan pada keimanan yang benar (Sabib) dan amal saleh yang di lakukannya. ${ }^{15}$

Pemahaman yang lebih kontemporer tentang konsep keselamatan di kemukakan oleh Muhammad Syahrur. Ketika menafsirkan (Qs. AlBaqarah: 62) menjelaskan bahwa definisi Islam menurut ayat tersebut adalah mengakui adanya Allah, beriman pada hari akhir dan beramal shaleh. Dengan demikian, siapa saja yang memiliki ketiga sifat itu disebut sebagai muslim, tanpa melihat apakah dia termasuk pengikut Muhammad

${ }^{13}$ Rasyid Ridha,Tafsir Al-Manar, Jilid IV, hal. 287-288.

${ }^{14}$ Diambil dari Fathimah Usman, Wabdat al-Adyan, (Yogyakarta, Lkis, 2002), hal. 69-75

${ }^{15}$ Rasyid Ridha,Tafsir Al-Manar, Jilid IV, Cet. Ke-3, t.th. hal. 257 Beirut: Dar al-Fikr dan Lihat juga Rasyid Rida, Tafsir al-Qur'an Al-Hakim, hal. 336. 
(alladzina 'Amanu), pengikut Musa (al-Yabud), Isa (An-Nasara) atau pengikut jalan keselamatan lainnya. ${ }^{16}$

Dari pandangan ini kemudian Syahrur merekontruksikan bangunan rukun Iman kedalam tiga hal, yakni 1.Beriman pada Allah, 2.Beriman kepada hari akhir, 3. Beramal Shaleh. Dia juga menegaskan bahwa kebenaran religius (Truth) bisa datang dari setiap agama di dunia dan keselamatan (Salvation) bisa diperoleh oleh setiap pemeluk agama apapun. ${ }^{17}$

Pandangan senada juga dikemukakan oleh Muhammad Asad yang mengomentari ayat diatas, yaitu:

"The Above passege-which recurs in the qur'an several times lays down a fundamental doctrine of Islam. With a breadth of vision un paralleled in any other religius farth, the idea of "Salavation" is here made conditional upon theree elements only: belief in god belief in the day of judgment, and rightous action in life, the statement of thus dovtribe at this juncture - that is, in the midst of an appeal to the children of israel - is warranted by the false jewish belief that their descent from Abraham entitles them to beregarded as "god's chosen people". ${ }^{18}$

(Firman diatas yang disebut beberapa kali dalam al-Qur'an meletakkan suatu doktrin dasar Islam. Dengan keluasan pandangan yang tidak ada bandingannya dalam kepercayaannya agama lain manapun juga, ide tentang "keselamatan" disini dibuat tergantung hanya kepada tiga unsur percaya pada Tuhan, percaya pada hari akhir, dan tindakan penuh kebaikan dalam hidup, di kemukakannya doktrin itu dalam kaitannya dengan masalah ini yakni dalam rangka seruan kepada anak Israel - dapat dibenarkan karena adanya keyakinan palsu Yahudi bahwa kenyataan mereka untuk dipandang sebagai "Manusia pilihan Tuhan").

Dari penjelasan Muhammad Asad diatas, Firman Allah tersebut diturunkan untuk menegaskan bahwa siapapun dapat memperoleh keselamatan (salvation) selama dia tetap beriman pada Allah, hari akhir dan berbuat baik, apakah dia termasuk keturunan Nabi Ibrahim atau bukan.

${ }^{16}$ Muhammad Syahrur, Al-Islam wa Al-Iman, Manzumat al-Qiyam, (Damaskus : Al-Ahali li At-Tiba'ah wa an-Nasyir wa at-tawzi'i, 1996, hal, 37.

${ }^{17}$ Ibid., hal. 38

${ }^{18}$ Muhammad Asad, The Meassage of the Qur'an, (London: E.J. Brill. 1980), hal. 14. 
Jika penafsiran tekstual menganggap bahwa hanya ada satu agama yang mempunyai keselamatan hakiki, yaitu agama Islam. Sedangkan penafsiran yang berorientasi kontekstual meyakini bahwa keselamatan (Salvation) adalah milik semua golongan, yaitu siapa saja yang beriman kepada Allah dan hari akhir serta beramal baik dari manapun asalnya baik Islam, yahudi, Nasrani maupun sabi'in. Pandangan penganut tafsir kontekstual ini menurut penulis dapat dimasukkan pada paradigma inklusif, yaitu pandangan yang meyakini bahwa keselamatan dapat di peroleh oleh setiap pemeluk agama, apapun agama yang dianutnya selama mereka beriman dan beramal shaleh, sebagaimana di isyaratkan dalam Islam.

\section{Konsep Keselamatan dalam Sorotan}

Doktrin keselamatan (salvation) merupakan konsep penting yang secara umum terdapat pada setiap agama.Oleh karena itu, masing-masing agama mengklaim dirinya sebagai juru selamat (Salvator) bagi masing-masing pemeluknya. Dalam agama kristen protestan misalnya, terdapat sebuah doktrin yang dikenal dengan No Salvation Outside Christianity, diluar kristen tidakada keselamatan. Demikian juga di dalam agama Kristen Katolik, berpegang pada, satu doktrin yang menyebutkan Extra Ecclesiam Nulla Salus, diluar gereja tidak ada keselamatan. ${ }^{19}$ Bagi penganut Yudaisme, doktrin "The Chosen People" menjadi landasan teologis mereka bahwa hanya etnis Yahudi saja yang akan memperoleh keselamatan. Sedangkan dalam agama Islam sendiri, argumen teologis tentang keselamatan sebagai milik mereka didasarkan pada doktrin keterputusan akhir (Super cessionism), yaitu suatu aturan (Kristen dan Yahudi) tetap sah sebelum datangnya aturan baru (Islam) yang menggantikan aturan lama, maka aturan yang baru itu dengan sendirinya membatalkan aturan yang sebelumnya. Argumen ini didasarkan terutama pada ayat (إن الد ين عند الله الاء سلام (إ).

Jika ditelisik secara historis, semua agama tanpa terkecuali, baik yang teristik maupun non-teistik terlahir dan memiliki klaim kebenaran tentang jaminan keselamatan, baik ia dinyatakan secara eksplisit maupun implisit. Dengan kata lain, tidak ada agama yang tidak memiliki doktrin

${ }^{19}$ Doktrin dalam sekte tertentu dalam agama Kristen Katolik ini didasarkan pada fakta sebelum Konsili Vatikan II 
keselamatan karena tanpa klaim keselamatan adalah suatu yang sudah inheren didalam setiap agama. Oleh karena itu, Ismail Raji al-Faruqi, menjelaskan bahwa klaim kebenaran merupakan hal yang esensial dalam agama.Penonjolan keagamaan tidak semata-mata satu diantara sekian proposisi, namun ia sebenarnya bersifat unik eksklusif. ${ }^{20}$

Dalam setiap agama terdapat perbedaan yang cukup signifikan dalam memandang klaim keselamatan ini, jika dipetakan secara garis besar setidaknya terdapat 3 klasifikasi pandangan yang muncul berkaitan dengan klaim keselamatan, yaitu eksklusivisme, inklusivisme dan pluralisme. $^{21}$

Pertama, Eksklusivisme memandang bahwa klaim kebenaran dan keselamatan hanya dimiliki oleh agama tertentu secara eksklusif dan menegaskan kebenaran dan keselamatan yang ada di dalam agama lain. Klaim eksklusivisme ini tidak memberikan alternatif lain di luar perspektifnya sendiri. Ia tidak memberikan konsesi sedikitpun dan tidak mengenal kompromi. Pandangan ini, tentu saja memaknai kebenaran dan keselamatan (truth dan salvation) secara hitam - putih.

Kedua, Inklusivisme memandang klaim keselamatan secara lebih longgar, disatu pihak, pandangan ini masih meyakini bahwa hanya salah satu agama saja yang benar secara absolut, akan tetapi pandangan ini, dipihak lain, mencoba mengakomodasi konsep teologi keselamatan serta tranformasinya sehingga mencakup seluruh pengikut agama lain. Kalangan muslim yang menganut pandanganini meyakini bahwa pemeluk agama di luar Islam bisa memperoleh keselamatan selama mereka beriman dan berbuat amal shaleh yang menjadi syarat keselamatan dalam Islam.

Ketiga, pluralisme memandang bahwa doktrin keselamatan menurut para penganutnya - lebih bernuansa humanis ramah, santun, toleran, mencerahkan, demokratis dan prospektif. Pandangan ini dapat dilihat dari definisi yang di berikan oleh John Hick, seorang tokoh pluralis yang paling bertanggung jawab, ia mengatakan:

"Stated philosophically... pluralis the view that the great world faiths embody different perceptions and conceptions of and coorespondingly different

${ }^{20}$ Ismail raji al-Faruqi, Towards a Critical World Tebnologi, dalam the American Journul of Islamic Social Sciences, (Vol. 3 No. 1, September 1986), hal. 40

${ }^{21}$ John Hixk, Problems of Religoin Pluralism (Houndmills, Basings toke: the Macmillan press 1985), hal. 31-37. 
responses to, the real or the ultimate from within the major variant cultural ways of being human, and that within each of them the transformation of buman exixtence from self centeredness to reality centeredness is manifestly taking place - and taking palce, so far as human obsecation can tell, to much the same extent". ${ }^{22}$

Pernyataan diatas menunjukkan bahwa doktrin keselamatan bagi kalangan pluralis dimiliki oleh semua agama, baik yang teristik maupun non teristik dan dapat dianggap sebagai ruang-ruang soteriologis (Soteriological spaces) yang didalamnya atau “ jalan-jalan” sotariologis (soteriologi always) yang melaluinya, manusia bisa mendapatkan keselamatan (salvation), kebebasan (freedom) dan pencerahan (enlightenment). Mereka menganggap keselamatan yang ada pada agama-agama sebagai hal yang benar karena pada dasarnya, klaim tersebut sama-sama merupakan sebuah bentuk respon-respon otentik terhadap hakikat ketuhanan (the real) yang samasama transenden.Hanya saja Bentuk respon tersebut di ekspresikan secara berbeda-beda oleh masing-masing agama sesuai dengan keyakinan dan doktrin yang dimiliki. Oleh karena itu, dapat dikatakan bahwa klaim tersebut merupakan manifestasi-manifestasi otentik dari the real.

\section{E. Penutup}

Ada tiga kata kunci penting yang bermakna keselamatan dalam alQur'an, yakni $A n-N a j a h, A s-s a l a m$ dan Inqaz. Konsep keselamatan yang khusus menunjuk pada konsep keselamatan (Salvation) di akhirat adalah terma an-Najah yang di artikan sebagai jalan keselamatan yang akan diperoleh oleh orang-orang yang beriman kepada Allah dan berbuat kebajikan, Sedangkan konsep keselamatan yang terkandung dalam kata as-Salam, yang berarti perdamaian (Sulb) dan mencari selamat (Istislam) - Dalam ayat ini, konsep keselamatan di artikan sebagai selamat dari petaka, bahaya dan berbagai kesukaran seperti yang menimpa penduduk neraka. Terma lain yang juga mengandung konsep keselamatan adalah al-Inqaz, yang mengandung arti keselamatan yang berlaku di dunia dan akhirat. Jika dihubungkan ketiga paradigma tentang klaim keselamatan, khususnya keselamatan bagi non muslim, maka tafsir yang berorientasi tekstual pada prinsipnya bersifat eksklusif, yaitu memandang klaim

${ }^{22}$ Ibid., hal. 36 
kebenaran dan keselamatan secara ekslusif hanya dimiliki oleh kalangan orang-orang yang menganut Islam sebagai agama yang di bawa oleh Nabi Muhammad. Mayoritas penafsiran yang berorientasi tekstual meyakini bahwa hanya ada satu agama $(A l-D i n)$ yaitu Islam sebagai jalan keselamatan.

Sedangkan, tafsir yang berorientasi kontekstual menampilkan teksteks al-Qur'an yang berkaitan dengan keselamatan kaum non muslim dalam perspektif ketuhanan Universal dan Inklusivistik. Penafsiran yang cenderung kontekstual melihat kaum ahli kitab sebagai muslim karena mereka tetap menjalankan keimanan dan berbuat baik sehingga berhak untuk memperoleh keselamatan di akhirat. Syari'at yang diturunkan pada mereka adalah syari'at yang mengandung ajaran monoteisme dan ketulusan beribadah pada Tuhan.Terkait dengan terma an-najah, tafsir kontekstual memahaminya dalam konteks keimanan monoteistik dan perbuatan amal shaleh tanpa memandang identitas keberagaman formal mereka.Hal ini sesuai dengan asumsi teologis penganut tafsir kontekstual bahwa keselamatan di akhirat menghendaki tiga syarat utama yaitu, Iman, Islam dan amal shaleh.Keselamatan tidak dapat di monopoli kaum muslimin semata, tetapi juga menjadi hak kaum non muslim selama mereka percaya beriman kepada Tuhan, percaya pada kenabian Muhammad dan mengerjakan amal shaleh. Keselamatan menjadi hak setiap orang yang beriman dan beramal saleh dari agama apapun mereka berasal. Dengan kata lain, setiap agama yang mengajarkan keimanan monoteistik terhadap Tuhan dan amal shaleh dapat menjadi jaminan bagi pemeluknya untuk memperoleh keselamatan dan rahmat di akhirat. Allah tidak akan menyia-nyiakan keberimanan seseorang dan kebaikannya, apapun identitas keagamaan yang dianutnya,meskipun secara "Syari'at" setiap orang atau kelompok memiliki jalannya masingmasing. Keimanan kepada Tuhan yang disertai perbuatan baik tetaplah bersifat lintas Agama (Cross - Religion). Keselamatan dan kebahagiaan di akhirat tidak didasarkan atas status agama (formal) seseorang, apakah ia seorang Muslim, Yahudi, Nasrani atau Sabi'in, tetapi lebih di dasarkan pada keimanan yang benar (Sabib) dan amal saleh yang di lakukannya. Kebenaran religius (Truth) bisa datang dari setiap agama di dunia dan keselamatan (Salvation) bisa diperoleh oleh setiap pemeluk agama apapun. (Wallahu A'lam Bisshowab). 


\section{Daftar Pustaka}

Fathimah Usman, Wabdat al-Adyan, Yogyakarta, LKis, 2002.

Ibnu Katsir, TafisrAl-Qur'an, Jilid II.

, Tafsir Al-Qur'an Al-Adzim, Jilid I, Beirut: Dar Al-Kutub AlIlmiyah, 2000.

Imam al-Baidawi, Tafsir al-Baidawi al-Musamma Anwar at-Tanzil wa Asrar at-Ta'wil, Jilid III, Beirut: Dar al-Fikr, 1996.

Ismail Raji al-Faruqi, Towards a Critical World Tehnologi, dalam the American Journul of Islamic Social Sciences, Vol. 3 No. 1, September 1986.

John Hick, Problems of Religion Pluralism, Houndmills, Basings Toke: The Macmillan Press, 1985.

Muhammad Asad, The Message of the Qur'an, London: E.J. Brill., 1980.

Muhammad Syahrur, Al-Islam wa Al-Iman, Manzumat al-Qiyam, Damaskus: Al-Ahali li At-Tiba'ah wa an-Nasyir wa at-Tawzìi, 1996.

Murthadha Muthahari, Keadilan Illahi,(Asas Pandangan Dunia Islam), terj. Agus Efendi, Bandung: Mizan, 1977.

Rasyid Ridha,Tafsir Al-Manar, Jilid IV, Cet. Ke-3, Beirut: Dar al-Fikr, t.th. ,Tafsir al-Qur'an Al-Hakim.

Sayyid Qutb, Fi Zilal Al-Qur'an, Jilid I, cet. Ke-21, Beirut: Dar al-Syuring, 1993. 